\title{
S \\ obre PRESEnÇa E REPRESENTAÇÃo NAS IMAGENS DOS SANTOS CATÓLICOS: CONSIDERAÇÕES A PARTIR DE UM ESTUDO SOBRE A DEVOÇÃo À SANTA RITA
}

\author{
Raquel dos Santos Sousa Lima \\ Colégio de Aplicação/Universidade Federal de Viçosa - Viçosa \\ Minas Gerais - Brasil
}

\section{Introdução}

As imagens tridimensionais dos santos católicos têm sido analisadas por uma ampla literatura - antropológica e histórica - a partir principalmente da discussão sobre as noções de presença e de representação. A imagem, palavra derivada do termo latino imago, apresenta valor semântico rico e variado, como nos lembra o historiador Jean-Claude Schmitt (2007); no que tange aos santos católicos, argumenta-se que elas os representariam, na medida em que seriam construídas a partir de momentos derivados das narrativas de suas vidas, que são incorporados em sua iconografia. Ao longo da história cristã, por conta de seu uso prático, as imagens teriam se metamorfoseado em presença, ultrapassando a função simbólica de representar e ser símbolo da história do santo (Belting 1994), algo que tem sido verificado não apenas do ponto de vista histórico, mas também antropológico.

Com base em minha pesquisa de doutorado (Lima 2014), realizada em uma igreja dedicada à Santa Rita de Cássia no centro da cidade do Rio de Janeiro, entre os anos 2009 e $2011^{1}$, apresento categorias "nativas" que sinalizam a necessidade de se complexificar as reflexões que têm sido desenvolvidas sobre o culto aos santos, re- 
ferentes às noções de presença e de representação. Indico ainda que essas categorias implicam o uso de outras concepções antropológicas importantes, que perpassam as relações com as imagens e os santos, como as de corpo e de pessoa.

\section{Apresentação do cenário e construção do problema}

Era véspera da Festa da Santa. A novena ${ }^{3}$ acabara de ser realizada, encerrando a missa das 18 horas. Como de costume, muitas pessoas deslocavam-se em direção a uma imagem de Santa Rita, que havia sido colocada perto do altar-mor, somente para os dias daquela celebração. Homens e mulheres aproximavam-se, nela tocavam, beijavam-na diretamente ou então beijavam suas próprias mãos e depois as encostavam na imagem, como se entregassem o beijo à santa. Outras pessoas, além desses atos, pegavam a fita lilás que pendia da imagem e, segurando-a, com ela faziam o sinal da cruz $^{4}$, passavam-na em seus próprios corpos, beijando-a também algumas vezes. Em meio à realização desses gestos pelos fiéis, reparei numa senhora que se dirigiu à uma imagem de Santa Rita que fica no altar perto da porta da entrada principal da igreja: olhou a santa, passou a mão em seus pés, voltou com a mão, tocando-a em seu próprio corpo; depois, dali, olhou para outra imagem de Santa Rita, localizada no altar-mor, que estava mais distante e no alto; a seguir, foi até uma terceira Santa Rita colocada em outro altar nos dias da novena, onde a tocou e à sua fita; enfim, a devota retornou para aquela imagem na qual tinha ido inicialmente e, de novo, a tocou e rezou.

Verifiquei que a devota realizava uma espécie de circuito, percorrendo todas as imagens, mas foi através do diálogo com ela que seu percurso ganhou sentidos mais definidos. Quando perguntei por que ela havia se dirigido a todas as imagens de Santa Rita, ouvi como resposta: "eu rezei para todas". Continuei: "mas a senhora já tinha ido naquela imagem ali, não é?”, apontando para a santa da entrada da igreja; e então ela disse: "eu voltei na de sempre, porque nela eu me sinto melhor. Eu não consigo ficar sem vir nesta santa daqui". Sua resposta me pareceu bastante instigante, posto que sinalizava uma questão importante: a de que alguns devotos teriam preferência por determinadas imagens da santa. Essa constatação, por sua vez, gerou outras indagações: por que eles escolhem uma santa específica para se relacionar se, a princípio, seriam todas Santa Rita? Elas seriam igualmente a mesma Santa Rita?

Há muitas imagens tridimensionais de Santa Rita no edifício que compõe a matriz, as quais são de variados tamanhos e suportes (como gesso, resina, madeira etc.). Elas ocupam diferentes lugares e algumas são destinadas para o culto público, isto é, estão situadas em altares ou sobre alguns móveis para aquilo que teologicamente é considerado veneração ${ }^{5}$ dos fiéis - uma grande quantidade delas é vista na loja de artigos religiosos daquela igreja. Podem ainda ser encontradas nos bancos do templo, depois de serem deixadas ou distribuídas diretamente às pessoas pelos próprios devotos, como pagamento de promessas e/ou agradecimento por graças rece- 
bidas, o que é feito tanto por meio de imagens em papel, como os santinhos, quanto pelas tridimensionais, como as estátuas pequenas. São seis as principais imagens do culto na igreja, as quais se localizam em diferentes pontos do templo, como vemos nas figuras abaixo ${ }^{6}$ :

SR 1

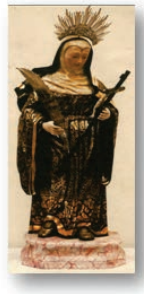

SR 2

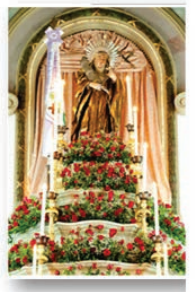

SR 3

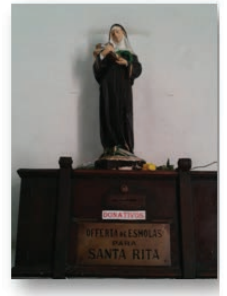

SR 4

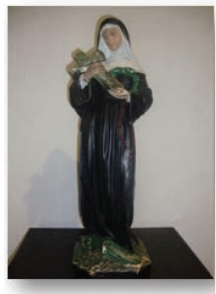

SR 5

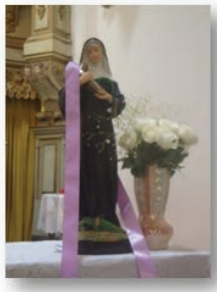

SR 6

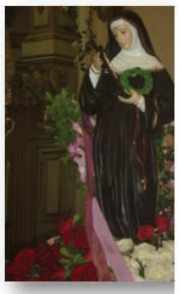

Figura 1: As diferentes Santa Rita da igreja.

Fonte: Raquel Lima.

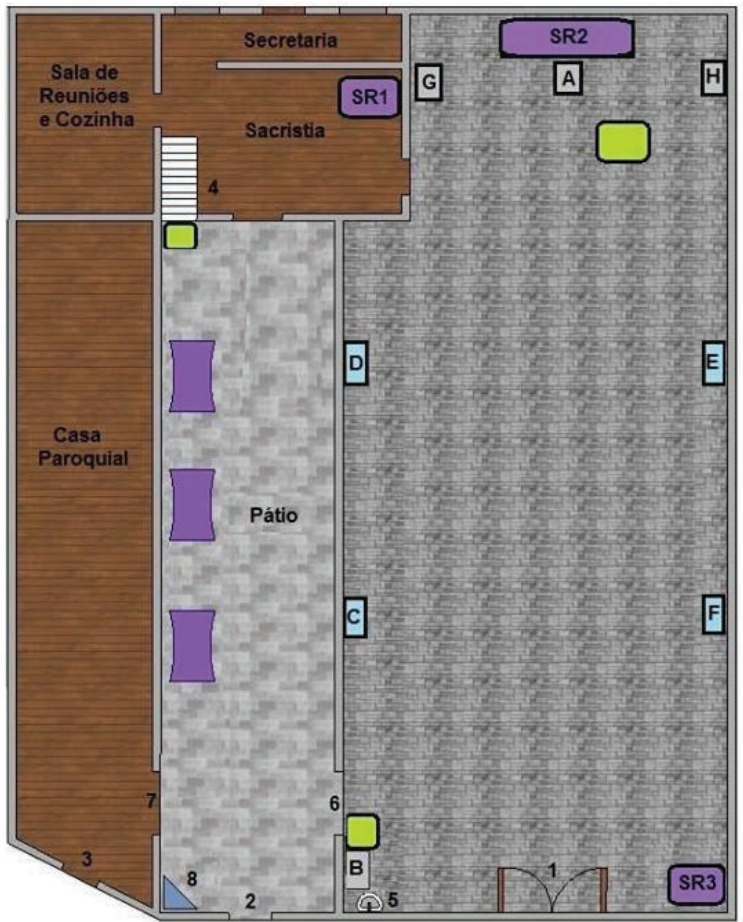

LEGENDA:

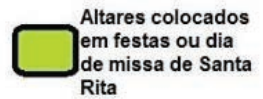

A- Nossa S. da Conceição

B- Santo Antônio

C. Altar de São Miguel Arcanjo

D- Altar de São Sebastião

E-Altar de Nossa S. das Dores

F- Altar de Sant'Anna Mestra

G. Santo Agostinho

H. Santo Avelino

SR1 - Altar com Santa Rita

$$
\text { e reliquias }
$$

SR2 - Altar-mor : Santa Rita

SR3 - Santa Rita

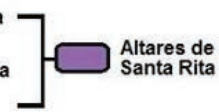
1- Entrada principal
2- Entrada lateral
3- Entrada da Casa Paroquial
4-Escada
5. Pia batismal
6-Porta para o pátio
7. Porta para a casa paroquial
8- Ofertório para diversos santos

Figura 2: Esboço da igreja com as imagens da santa no dia de sua festa. Fonte: Raquel Lima. 
As três primeiras imagens da santa são fixas, isto é, podem ser visitadas a qualquer época do ano, no mesmo lugar: uma no altar da sacristia (SR1), outra no altar-mor do templo (SR2), e a terceira, colocada sob um pedestal, à direita da porta principal da igreja (SR3). Essas são as imagens mais procuradas pelos fiéis, tanto no dia a dia, quanto nos eventos comemorativos da santa. As outras (SR4, SR5 e SR6) geralmente são colocadas em altares ou sobre algum móvel para a realização de celebrações, sendo retiradas logo após, embora seja possível encontrar a SR4, por exemplo, em um desses lugares num dia qualquer. A figura SR5, quando é utilizada no período da novena, às vezes recebe uma fita lilás e costuma permanecer guardada pelo resto do ano. Da mesma maneira, a SR6 fica preservada, já que é destinada à procissão, que ocorre só durante a festa.

Como podemos observar pelas fotos apresentadas, há dois estilos básicos nas imagens da santa naquela igreja ${ }^{7}$. Duas são mais antigas (SR1 e SR2) e têm aproximadamente um metro e meio, seguindo o padrão barroco do século XVIII: são rebuscadas, pintadas com ornamentos dourados; portam uma coroa de prata; apresentam a marca do estigma; seguram uma palma na mão direita e um crucifixo na esquerda. Ambas teriam sido trazidas de Portugal, e a primeira, de 1750, ocupa o altar da sacristia, enquanto a outra, de 1765, fica no altar-mor e seria uma "cópia idêntica" daquela (SR1) ${ }^{8}$. Já no outro modelo, do qual há várias réplicas (SR3, SR4, SR5 e SR6), a santa aparece vestindo um hábito preto liso, com um cinto característico da ordem agostiniana; porta uma coroa de espinhos atrás de sua mão esquerda e, com as duas mãos, segura um crucifixo, olhando-o; tem na fronte o sinal vermelho, além da palma, que nas imagens barrocas está nas mãos de Santa Rita, mas nestas aparece sobre seus pés. A coroa de espinhos, a marca do estigma e o crucifixo são os atributos mais comuns nas imagens (re)produzidas de Santa Rita e salientam uma passagem em que a então monja agostiniana Rita, após ter pedido a Jesus Cristo que ele compartilhasse com ela as dores de sua Paixão, recebe deste uma chaga, um espinho de sua coroa, que se desprende, fixando-se na fronte da santa (Scaraffia 1990). Além desses atributos, sua iconografia ainda comporta três coroas que circundam a palma, as quais, de acordo com duas vendedoras da loja, seriam "as três virtudes de Santa Rita, como filha, mãe e esposa", mostrando o martírio da santa, em todas as fases de sua vida9. Ao longo deste artigo, voltarei a essas descrições, que serão retomadas para pensar as formas pelas quais os devotos percebem ou constroem suas representações sobre Santa Rita e suas interações com ela.

\section{Critérios de classificação das imagens}

$\mathrm{O}$ fato de haver muitas imagens de santos na igreja como um todo ${ }^{10} \mathrm{e}$ o de aquelas de Santa Rita não serem todas iguais em sua dimensão estética formal trazem, eventualmente, algumas dúvidas para os devotos: "qual dessas é Santa Rita?" e "onde está Santa Rita?" são perguntas que ouvi várias vezes em campo. Ao comentar 
com o pároco que uma senhora que entrara na igreja pela primeira vez havia me perguntado qual das imagens era Santa Rita, ouvi a seguinte frase: "não são imagens, são todas Santa Rita, Raquel!”. Embora exista uma orientação canônica de que as imagens de culto devam ser consideradas como representações das pessoas dos santos, o próprio clérigo, como membro da hierarquia eclesiástica, contraria a sugestão teológica, já que opera com a ideia de presença, ao dizer que elas não são imagens, e sim a própria santa.

Do ponto de vista dos fiéis, a noção de representação também cede lugar à verificação da presença da santa, pois eles afirmam: "Para mim não é imagem. É como se fosse a imagem de uma pessoa que a gente ama, que a gente venera" (devota 1); "É imagem sim, mas Santa Rita está ali presente" (devota 2); "Sei que é uma imagem, mas tem a presença de Santa Rita ali" (devota 3).

As observações feitas na igreja de Santa Rita, no Rio de Janeiro, reforçam o que a história do culto aos santos, com suas variações, tem mostrado desde seus primórdios: que os devotos tratam as imagens e também as relíquias como se fossem pessoas, e não como algo que evocaria ou representaria os santos, mas que os "pre-

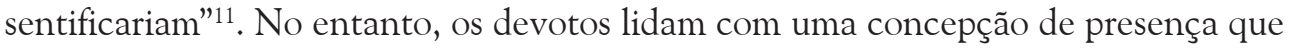
é ao mesmo tempo simples e complexa: para uns, é uma imagem na qual estaria Santa Rita, mas, na visão de outros, é uma não imagem, "como se fosse" pessoa. Sob esse aspecto, o termo "como se" apresenta-se como um recurso de linguagem que permite marcar a ambiguidade de não ser, mas parecer ser, ao mesmo tempo em que nos remete para a ambivalência de ser e não ser ${ }^{12}$.

Se tomarmos a expressão "como se" a partir das sugestões do linguista Roman Jakobson (1971), é possível afirmar que a metáfora "é como se fosse Santa Rita” implica uma linha semântica que, por similaridade, leva a imagem à santa, ou seja, há uma associação entre o que deveria ser um signo da santa - a sua imagem - e ela mesma - Santa Rita. Os devotos, padres, entre outras pessoas, dão significados múltiplos, ambivalentes e às vezes ambíguos para as imagens de Santa Rita, mostrando que este processo de personalização é complexo e aciona jogos metafóricos e/ou metonímicos, evidenciando que os processos de produção simbólica envolvem a utilização de figuras de linguagem, com as quais tais processos se articulam, complexificando-se.

Esta discussão pode ser desdobrada de diferentes maneiras, mas, por ora, gostaria de retomar a fala do padre, dessa vez para pensar naquilo a que ela se contrapõe em relação ao que pensam os devotos. Como vimos, o clérigo afirmou que "todas" as imagens "eram Santa Rita", mas meus interlocutores apresentam evidências de que elas não são vistas como sendo, todas, igualmente a mesma santa: "Tenho mais apego com esta santa" (devoto 1); "Esta é meu xodó" (devota 4); "Tenho um carinho especial por esta" (devoto 2); "Esta aqui é minha preferida" (devota 5).

As designações afetivas de "carinho", "apego", "xodó", bem como a fala daquela devota que fez um circuito percorrendo várias imagens da santa, revelam que há predileção por algumas delas, o que me leva a cogitar se eles estariam se referindo 


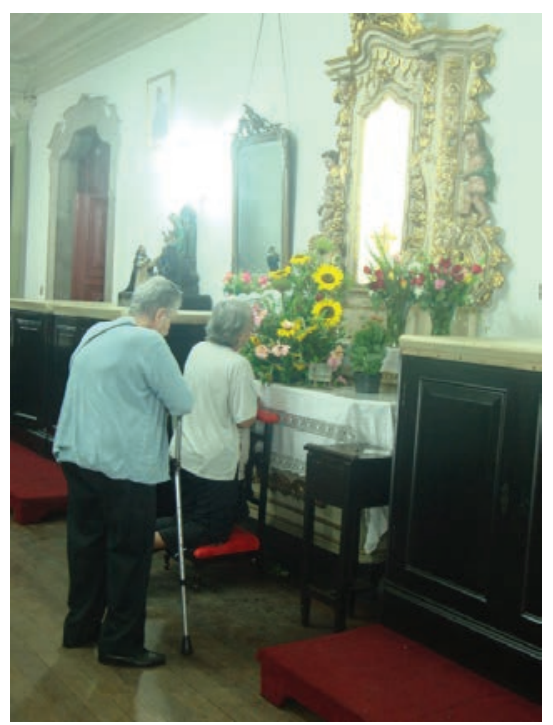

Figura 3: Devotas diante do altar da sacristia.

Fonte: Raquel Lima.

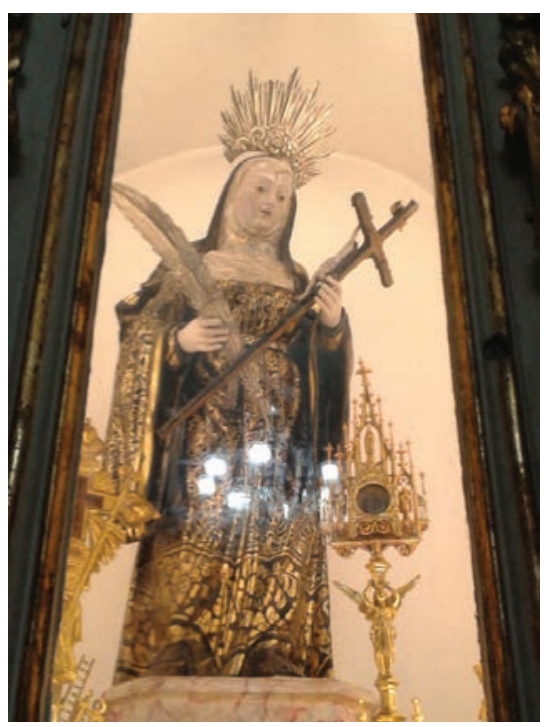

Figura 4: Uma das Santa Rita (SR1) mais queridas, a do altar da sacristia. Fonte: Raquel Lima. à mesma Santa Rita. Ou seja, há um processo de construção de preferências por determinadas santas, e este opera a partir de determinados critérios de classificação, que implicam uma ordem hierárquica entre as imagens (Mauss e Durkheim 2001). Isso, por sua vez, permite afirmar que a ideia da presença dos santos nas imagens é algo mais complexo do que tem sido tratado em alguns estudos, pois não basta dizer que a imagem presentifica o santo. Há sutilezas em relação à forma como a presença é concebida, e isso sinaliza a necessidade de refinarmos nossas interpretações a partir de elementos etnográficos. No caso dos fiéis de Santa Rita aqui em análise, a presença da santa manifesta-se principalmente na interação entre os devotos e as imagens.

Há muitas possibilidades de interagir com Santa Rita e as maneiras de se relacionar com ela dependem, muitas vezes, da disposição física de suas imagens. Com as que estão mais distantes, pode-se principalmente olhar, rezar, conversar, mandar beijos; já com aquelas que ficam fisicamente mais próximas dos devotos é possível também tocar, beijar e até abraçar. Em geral, esses gestos são precedidos ou finalizados com o sinal da cruz, e os atos de rezar, olhar, beijar, podem tanto ser feitos separadamente, um antes do outro, quanto ao mesmo tempo. Em diálogo com a antropóloga Renata Menezes (2004b), que já havia indicado a centralidade das imagens nas manifestações públicas endereçadas aos santos, mostro que as diferentes maneiras que os fiéis têm de se relacionar com as imagens revelam que se comunicar com a santa, interagindo com suas imagens, é parte essencial da devoção, ao mesmo tempo em que aponto a complexidade que essas interações envolvem.

Uma das imagens mais "queridas" pelos devotos de Santa Rita é aquela que fica 
no oratório da sacristia e, para se compreender a preferência por ela, é preciso levar em conta dois elementos importantes que foram salientados pelos fiéis. Um deles é a disposição espacial do altar, que faz com que a santa fique mais próxima e acessível aos olhos e aos toques dos devotos, ainda que estes sejam intermediados por um vidro que os separa ${ }^{13}$. O segundo elemento, que se relaciona com o primeiro, é a infraestrutura fornecida pela igreja, que deixa um genuflexório - móvel usado para que os fiéis possam ajoelhar-se para rezar - em uma posição assimétrica em relação à santa, embora alguns devotos não o utilizem, permanecendo em pé durante suas orações (ver figuras ao lado).

O altar é preparado pela igreja, mas é constantemente (re)construído pelos devotos que, em suas interações naquele espaço, levam orações, fotografias e eventualmente ex-votos ${ }^{14}$. Porém, uma das maneiras mais comuns que eles têm de compor aquele espaço é por meio do oferecimento de rosas à santa, uma prática frequente, tanto no dia a dia quanto na festa, quando ocorre uma importante troca ritual de rosas ${ }^{15}$. Esse é um fator muito significativo na construção da primazia dos devotos por aquela imagem: "Esta é minha preferida, porque posso trazer rosas para ela" (devota 6).

A organização espacial nos rituais é um elemento importante de sua constituição (Kondo 1984) e, no caso de Santa Rita, esse aspecto pode ser determinante, pois a aproximação física com a imagem permite aos fiéis terem percepções sobre a santa, ao mesmo tempo em que permite à santa se manifestar para eles: "Essa daqui eu sinto a expressão dela" (devota 7); "Olha como ela está sorrindo hoje!" (devota 8); "Raquel, olha como ela gosta de receber rosas!" (devota 9).

A proximidade física é potencialmente capaz de criar aproximação afetiva, na medida em que torna mais fácil para a santa e para seus devotos se perceberem mutuamente. Mas nem sempre o afeto decorre do fato de se estar fisicamente mais perto da santa. Duas senhoras que têm como preferida a santa do altar-mor (SR2), aquela que só pode ser vista de longe, disseram: "Eu sofria muito com meu ex-marido, que bebia, me agredia. Aí eu vinha aqui nesta santa e chorava, rezava, falava com ela, até que um dia consegui meu divórcio" (devota 1); "Essa aqui é meu porto seguro. Quando minha mãe ficou doente era aqui que eu rezava, e Santa Rita curou ela" (devota 5).

Vemos que, para além dos fatores físicos, há registros afetivos importantes, marcados pelos lugares e pelas situações em que as vidas das devotas e a da santa se tornam relacionadas ${ }^{16}$. Ou seja, existem balizamentos densos que os sujeitos elegem na tessitura da narrativa de suas vidas, os quais podem atuar como elementos hierarquizadores na elaboração da preferência por uma imagem específica de Santa Rita. Dessa forma, os processos de apropriação desse lugar são complexos, envolvendo condições que agem como ordenadoras na definição da primazia por uma determinada santa com a qual se relacionar. É interessante que essas hierarquias construídas pela proximidade física ou pelo afeto determinem, mais que os atributos propriamente ditos da iconografia da santa, a predileção por uma ou outra imagem. 


\section{As modalidades de interação com Santa Rita}

A localização das imagens e suas formas de classificação relacionam-se com outra questão importante: a da existência de diferentes modalidades de interação com Santa Rita. Neste trabalho, a recuperação das maneiras de interagir com a santa foi uma estratégia metodológica que permitiu recuperar as múltiplas formas pelas quais os fiéis concebem Santa Rita, sua pessoa e seu corpo.

Quando eu, ao ver as pessoas com as mãos nas imagens, perguntava o que elas estavam fazendo e por que faziam aquilo, percebi que muitas se referiam ao gesto realizado usando o verbo "tocar": "Estou tocando Santa Rita" (devota 10).

As pessoas mais socializadas no catolicismo sabem que o ato de tocar as imagens de santos é algo comum entre os devotos, como também o sabem diferentes autores que trataram do tema ${ }^{17}$. Uma das interpretações mais comuns é a de que o ato estaria relacionado a uma intenção específica, a de se obter algo da santa; o objetivo último do desejo religioso do devoto não seria ver, mas tocar; em troca, ele esperaria ser tocado pelo objeto de sua visão (Miles 1998). De fato, percebi que muitos fiéis, ao entrarem em contato com Santa Rita, tentam capturar propriedades específicas da santa ou que possam ser transmitidas por ela, como a fé, a leveza, uma bênção, uma energia boa, um fluido, tranquilidade, etc.: "Acho que vem algum fluido quando eu toco ela. Algo de bom vem dali, algo de bom adquire ali" (devota 12).

Mas nem sempre o gesto de "tocar" ou "colocar" a mão (um termo também encontrado) tem como finalidade receber algo que a santa seja capaz de transferir, e pode estar mais relacionado à necessidade de os devotos sentirem a santa: "Eu toco pra sentir que ela está aqui" (devota 2); "Nós brasileiros, precisamos tocar, ter sensação de que somos pertencentes à Santa Rita" (devoto 3).

A referência a uma técnica corporal (Mauss 1974) tida como característica dos brasileiros - tocar as pessoas durante uma conversa - é acionada pelos devotos, que fazem desse aspecto cultural mais amplo uma argumentação para pensar sua relação com Santa Rita, o que indica o potencial que as imagens têm de dizer sobre os processos sociais e culturais (King 2010). Mas a questão principal que gostaria de trazer para me inserir nesse debate é que, quando eu os perguntava sobre o que faziam, alguns devotos disseram: "estou fazendo um carinho", "estou passando a mão"; ou, então, "eu boto a mão". Fui observando que, conforme as pessoas usavam outros verbos para falar sobre o ato de por a mão na imagem da santa, a conotação ganhava ares diferenciados, como no caso das expressões a seguir: "Passo a mão para agradecer e não para fazer pedido" (devota 8$)$.

Os relatos indicam que os fiéis dão designações diferentes para o ato que a literatura trata como "tocar" e, sob esse aspecto, o enquadramento dos gestos a partir de outras categorias nos revela que há significados diferentes para eles, os quais salientam outras modalidades de interação com Santa Rita, o que, por sua vez, complexifica a forma como o tema do toque tem sido interpretado academicamente. Ao co- 
mentar sobre as análises dos rituais Ndembu feitas por Victor Turner (1967), Stanley Tambiah (1985) alega que ele não focalizou o problema particular da alternância de formas verbais e sugere que prestar atenção neste quadro analítico lançaria luz nos estudos sobre ritual. Inspirando-me nessa formulação para pensar as interações com Santa Rita, destaco que há evidências de que os verbos utilizados para expressá-las designam gestos que adquirem sentidos múltiplos. "Passar" ou "botar" a mão, por exemplo, é um termo mais usado para se referir ao ato de agradecer, sem que se esteja fazendo um pedido ou querendo obter algo da santa. Vejamos outro caso: "Eu tô passando a mão só pra fazer um carinho nela" (devota 13); "Eu passo a mão na santa para dar carinho. A gente não gosta de carinho?" (devota 14).

Aqui o intento é "dar" algo para a santa, e não "receber" algo dela, finalidade que nos remete à noção da graça, já que o ato é relacionado à doação do devoto, e não à de Santa Rita. Esta é uma questão importante, pois nos estudos sobre o culto aos santos há uma chave analítica consolidada, que trata as relações entre os devotos e seus santos como relações interessadas de troca. De acordo com Menezes (2010, manuscrito), tais relações se materializariam em três etapas: "a promessa (o pedido), a concessão do que se quer pelo santo (ou por Deus, através da mediação do santo), e o pagamento da promessa"; no entanto, defende a autora, a troca seria apenas mais um momento da relaçãa ${ }^{18}$.

No processo de recompor as interações dos fiéis de Santa Rita com suas imagens, vejo que elas corroboram as reflexões tecidas pela antropóloga mencionada acima, pois, quando a devota passa a mão "para dar carinho", indica que a relação com a santa extrapola a chave analítica baseada nas leituras mais mecânicas e reducionistas do ensaio sobre a dádiva de Marcel Mauss (2004), como as que tratam o "dar-receber-retribuir" de forma muito linear e automática. Na verdade, diz Menezes (2010), as coisas são mais complexas, e não é um jogo de equilíbrio ou de vantagens - que tanto inspirou os trabalhos sobre as devoções aos santos - o que se busca nas trocas simbólicas. Passar a mão configura-se, assim, como um ato de autoentrega no qual o dar (carinho) prevalece sobre o receber (graças, promessas etc.), evidenciando a complexidade da devoção.

\section{O respeito no contato com Santa Rita}

É preciso ressaltar que, embora o ato de tocar ou de passar a mão nas imagens de santos seja comum entre os devotos, não é em qualquer lugar, nem de qualquer maneira, e nem da mesma forma que as pessoas fazem isso. A partir de um trabalho minucioso de observação, verifiquei que há muitas variações: algumas pessoas apenas colocam rapidamente as mãos sobre uma parte da imagem; outras, às vezes, passam a mão sobre todo o corpo da imagem, fixando-as depois por alguns segundos em uma determinada parte; umas passam suas mãos sobre a santa sem parar. Há um tratamento diferenciado das imagens, e a localização destas na igreja, bem como os 
suportes que a sustentam, influencia e muitas vezes determina a parte da imagem a ser alcançada e, consequentemente, a ser tocada pelo fiel: "Eu coloco as mãos nos pés, porque é onde dá para colocar a mão nela” (devoto 4).

Este relato aplica-se ao que ocorre diante da imagem que fica na entrada da igreja, a qual, por estar sobre um pedestal alto, pode ser alcançada apenas na parte de seus pés, evidenciando como o toque pode ser determinado pelos limites físicos. Algo parecido acontece diante da imagem da sacristia, que também é fixada em um nicho alto, só que nesta o ato se torna mais complexo, pois embora os devotos tentem aproximar suas mãos dos pés da santa, estes não são propriamente tocados, devido à existência de um vidro protegendo-a e ao mesmo tempo separando-a dos fiéis. Como já indiquei, o vidro, apesar de (aparentemente) separar a imagem dos devotos, pode ser pensado, por meio das associações metonímicas feitas por eles, como extensão de Santa Rita, o que me leva a cogitar se as pessoas, ao tocarem o vidro na direção dos pés da imagem, não estariam, em certo sentido, tocando os próprios pés da santa.

Mas a questão que eu gostaria de enfatizar é que há relatos de fiéis que dizem ter preferência por certas partes, mesmo quando se encontram diante de uma imagem que pode ser inteiramente acessada e tocada. Muitos manifestam preferir os pés: "Gosto de tocar os pés" (devoto 5); "Gosto de tocar mais nos pés porque é a minha humildade diante de um personagem público muito mais forte que eu" (devota 15).

Quero com esses relatos salientar que, independentemente da posição em que as imagens estejam em relação aos devotos, seus pés constituem uma das partes mais procuradas por eles; não apenas os de Santa Rita, mas os dos santos em geral. Alguns devotos explicam essa preferência acionando a noção de humildade, que seria um elemento historicamente importante na composição dos gestos cristãos $^{19}$. A expressão de humildade perante a santa pode, algumas vezes, remeter a um jogo assimétrico, como percebemos na fala a seguir: "Passo as mãos nos pés, porque sou muito pequena para passar a mão na cabeça de Santa Rita" (devota 14).

A devota cria um par de oposições referente ao corpo da santa, no qual a posição física do que é mais alto (cabeça) estaria para a posição simbólica do que é mais sagrado, o mesmo valendo para o lugar mais baixo, os pés, associados com o lugar (baixo) da devota em relação à santa (alta). A estatura "pequena" dessa senhora exprime contornos simbólicos que evidenciam sua contraposição à grandeza de Santa Rita e, portanto, sua posição assimétrica, que faz com que ela possa tocar apenas os pés da santa. Dessa forma, o relato da devota articula, por meio dos gestos corporais direcionados às imagens de Santa Rita, a ideia da humildade.

Mas nem todos os devotos concebem seus gestos a partir da perspectiva da humildade perante a santa, sendo possível que outras motivações entrem em jogo: "Gosto de tocar sempre os pés, de qualquer santo. Eu acho que é respeito, eu não vou beijar o rosto dos santos" (devota 10); "Eu toco sempre nos pés dos santos, mas em santo Antônio que tenho em casa não preciso tocar, eu beijo, beijo os pés porque é respeito" (devota 11$)$. 
Embora alguns devotos tenham feito afirmações como "toco em qualquer lugar" ou "pode ser em qualquer lugar, mas gosto de pôr a mão nela", vemos que nem sempre é em qualquer parte ou de qualquer maneira que se pode ou se deve tocar nos santos. A noção de "respeito" aparece como um elemento forte da interação com as imagens, podendo até estar articulada à de humildade, como vemos: pode-se tocar e beijar os pés, mas não o rosto. Isso demonstra que os próprios devotos estabelecem limites na interação com elas, os quais variam de acordo, por exemplo, com o grau de intimidade na relação com um santo, como demonstra a devota que diz beijar os pés do santo que tem em casa, que é mais próximo dela, mas não os outros. Quanto mais íntimo de um santo, maior a probabilidade de realizar com ele algo considerado mais intenso: "Eu não passo a mão, eu beijo, eu acho que o beijo é mais profundo, né, do que passar a mão" (devota 16).

A categoria do "respeito", que é acionada por alguns como justificativa para não se beijar o santo ("eu não vou beijar o rosto dos santos"), é vista como motivo que leva outros a beijarem a imagem ("eu beijo os pés porque é respeito") ${ }^{20}$. Isso traz à tona a ambiguidade constante que permeia a devoção aos santos. Mas nem sempre as pessoas têm concepções elaboradas sobre os motivos que os levam a interagir com a santa de uma determinada maneira: "Não sei por que é que eu beijo Santa Rita. A gente é macaco de imitação. Mas parece que o pedido é aceito melhor" (devoto 6).

As motivações para beijar a santa podem ocorrer no nível do indivíduo, mas podem passar por padrões, ou seja, por aspectos mais convencionais, influenciados por consensos dentro de uma comunidade de devotos, por exemplo.

Durante a Festa de 2011, enquanto eu conversava com uma vendedora da barraquinha de artigos religiosos, observei um senhor que chegou perguntando a ela como deveria fazer para limpar a imagem de Santa Rita, que tinha em sua casa. Isso porque, segundo ele, como ela ficava no corredor perto da cozinha, estaria "muito engordurada". A vendedora comentou que ele podia limpá-la, dizendo: "você pode limpar, você não vai ser castigado porque está limpando a santa". A fim de ensiná-lo, passou a narrar como fazia com suas próprias imagens: "Eu lavo Santa Rita com sabonete. Não vou pegar pano de cozinha para lavar a santa. Santo a gente trata com mais respeito, não porque a gente adora, mas porque olha para ela e está pensando em Deus. Não passo nada velho na santa, só uso esponja nova ou pano novo para limpar" (vendedora). O senhor, então, disse que iria lavar sua imagem como ela ensinara. A vendedora, já concluindo a conversa, falou ainda que sua irmã passava um perfume que gostava na santa: "é um agrado que faz a ela [à santa]".

Esses relatos evidenciam que há um tratamento respeitoso e de humildade diante do santo, trato que pode ser pensado como uma espécie de "etiqueta"21. Tal como há uma etiqueta do pedido escrito aos santos, existe uma forma adequada de se dirigir às imagens de Santa Rita e de se relacionar com elas, da mesma maneira que existem algumas pessoas mais aptas para hierarquizar esses comportamentos, como salienta a narrativa da vendedora mencionada anteriormente. Além disso, o próprio 
ato de ir à igreja para dirimir as dúvidas sobre o que fazer com as imagens pode, por sua vez, ser visto como constituinte desse conjunto de formalidades que devem ser seguidas no tratamento respeitoso de uma imagem de santo. Entretanto, pode-se argumentar que a noção de respeito se conjuga com outro aspecto comum no trato das imagens: o da hesitação de não se saber o que fazer diante delas ou com elas, como o iconoclash de Bruno Latour (2008) 22 .

Isso parece se aplicar às pessoas que, durante a festa, perguntavam onde poderiam deixar as imagens que traziam em suas mãos, como mostra essa ex-devota: "Eu era devota de Santa Rita, mas agora me tornei evangélica, mas não quero jogar a imagem da santa no lixo, então resolvi trazer para deixar ela aqui na igreja".

$\mathrm{O}$ ato de entregar a imagem à igreja pode ser uma forma respeitosa de lidar com a santa, mas é preciso considerar o lado negativo do poder das imagens (Freedberg 1992), que pode preocupar as pessoas. O receio com a potencialidade desconhecida das imagens ajuda a entender a orientação que os funcionários que cuidavam da limpeza daquele templo tinham, de jogar no lixo as imagens que fossem encontradas nos bancos, nos móveis, enfim, as que "aparecessem" sem que ninguém soubesse quem as havia deixado ali.

O respeito no tratamento das imagens de santo também se articula com outras dimensões, como as que envolvem as trocas comerciais, por exemplo. Ao acompanhar algumas pessoas que compravam imagens de Santa Rita numa das barraquinhas durante a Festa, ou mesmo ao conversar com elas em outros contextos, percebi que elas evitavam falar sobre aquela operação como "compra", ou seja, como algo que envolvia dinheiro: "Não se fala comprar. Minha avó ensinou que é trocar imagem, pois santo não se compra" (devota 17).

O uso do termo "trocar" mostra que as formalidades do tratamento respeitoso às imagens envolvem também um léxico específico, que perpassa a relação de devoção e, ao mesmo tempo, se conjuga com uma concepção de economia moral, de acordo com a qual coisas consideradas sagradas não devem ser comercializadas. As maneiras que os devotos de Santa Rita têm de tratar gestual e verbalmente as imagens, ao mostrarem que elas não podem ser "compradas" e que não é em qualquer lugar que se pode tocá-las, passar a mão nelas, ou mesmo descartá-las, jogando-as no lixo, por exemplo, revelam que esta etiqueta baseada na noção de respeito ao santo é permeada por jogos de aproximação e distanciamento com Santa Rita. Ao mesmo tempo, esses jogos acontecem porque, como as falas dos devotos nos deixam entrever, eles concebem as imagens de Santa Rita como sendo também o corpo da santa.

\section{(Re) composição do corpo de Santa Rita}

O historiador Jean-Claude Schmitt (2007) diz que o processo de atribuição da personalização às imagens seria algo entranhado no cristianismo, na medida em que este legitimou o recurso às imagens de tipo antropomórficas, atribuindo aparência de 
corpo humano aos seres sobrenaturais. Isso teria feito com que, ao longo do tempo, as imagens e esculturas de santos fossem concebidas como pessoas vivas, que falam aos homens, se movem, sangram, choram, curam milagrosamente as doenças que os devotos lhes imploraram.

Embora as análises histórico-iconográficas informem sobre o processo de personalização das imagens dos santos, as pesquisas de cunho etnográfico evidenciam que a associação do corpo dos santos aos dos humanos não é tão simples assim. Ao (re)compor o corpo de Santa Rita a partir das concepções de seus fiéis no Rio de Janeiro, percebi que muitos deles tomam por base, ao lidar com as imagens da santa, referências de suas relações com outras pessoas. Vimos anteriormente que muitos se referiram aos pés da santa; outros tantos citam as mãos da santa como sendo uma parte por meio da qual "a gente transmite energia". No entanto, as mãos de Santa Rita, como disse um senhor, transmitem mais que "energia", já que por ela também se dissemina a "graça", que é um componente essencial da devoção. Nesse sentido, embora possa ser considerado como tendo atributos de um corpo humano, o de Santa Rita não é um corpo qualquer, já que porta e transmite graça, purificação e proteção, coisas que as mãos humanas nem sempre fazem. O corpo da santa pode ser concebido de forma ainda mais complexa, como poderemos acompanhar a partir da fala a seguir: "Eu vou muito no peito dela, no peito é onde está Jesus, então eu toco não só nela, mas em Jesus também. Quando toco sinto a energia de Cristo. É como se ele estivesse ali no Crucifixo. Com a energia você se fortalece, é como se a energia que estivesse ali passasse para você" (devota 17).

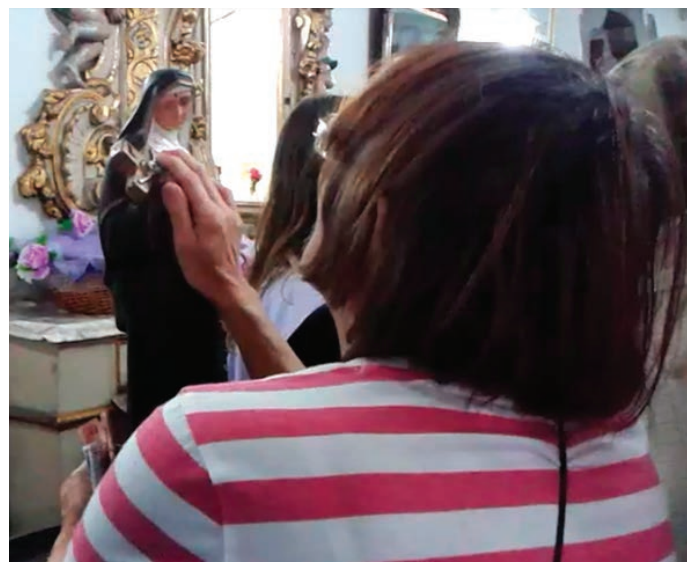

Figura 5: Devota "indo no peito de Santa Rita, onde está Jesus". Fonte: Raquel Lima.

Creio que o relato acima seja interessante para recuperarmos mais uma faceta das potencialidades em torno do culto a um determinado santo: a possibilidade de a imagem de um santo conter outro ser sagrado, numa espécie de fusão dos dois em um corpo. O conceito de participação de Lévy-Bruhl, tal como interpretado pelo antropólogo Márcio Goldman (1994), pode nos ajudar a pensar o corpo de Santa Rita, em suas "redes de ligações, interpenetrações e dependências" ${ }^{23}$ em relação ao de Cristo: a devota afirma que o peito é de Santa Rita, mas nele está Jesus; assim, ali, naquela parte, os dois estão juntos e, nesse sentido, Santa Rita pode ser ela e conter Jesus. Os atributos mais representados nas imagens de Santa Rita - o estigma e a cruz, que se referem a Cristo Crucificado - não são lembrados pela devota como um elemen- 
to associado à vida da santa. Ou seja, o atributo não é percebido por sua (suposta) capacidade indéxica de remeter ao episódio em que ela é estigmatizada; o atributo (que é um tipo de signo de Santa Rita) é visto como sendo o próprio Jesus. Esse caso mostra que em Santa Rita é possível uma assimilação com $\mathrm{Cristo}^{24}$, de forma que se apresenta plausível pensar no culto da santa como um culto ao próprio Jesus. Isso parece ficar bem evidente na fala da senhora que não se refere à Santa Rita e diz: "sinto a energia de Cristo". Seu relato, portanto, aponta para a ambivalência do corpo da santa. $O$ fato de o crucifixo ficar junto com o que os devotos supõem ${ }^{25}$ ser o coração da santa faz com que alguns deles, ao comentarem sobre o "peito" ou o "coração", estejam falando das duas partes ao mesmo tempo, o que corrobora a tese de que "o corpo não é uma entidade fechada ou separada do seu entorno por contornos bem definidos" (Rabelo 2011:26) ${ }^{26}$.

Faz-se necessário dar voz aos devotos, pois uma pesquisa baseada apenas na observação das expressões corporais de devoção não conseguiria recuperar os sentidos dados e as singularidades percebidas nos comentários que os fiéis fazem sobre suas interações com Santa Rita. Sob esse aspecto, o episódio que passarei a recuperar agora é precioso. Ao ver uma senhora passando suas mãos na imagem da santa, perguntei o que ela estava fazendo, e então começamos a conversar sobre as imagens que ela tem em casa. A devota fez um relato interessante, dizendo:

Eu boto a mão, eu faço assim [mostra passando a mão na parede de cima para baixo, como se acariciasse]: ah, me abençoa Santa Rita, e passo a mão nela. Pessoas de outras religiões confundem, mas para nós não é imagem. Toco o coração e os pés. Eu digo: Santa Rita, eu tô tocando o coração da senhora para a senhora tocar o coração de meus filhos (devota 1).

Essa senhora disse que fazia isso todo dia. Pedi que repetisse para mim o que dizia para a santa, e ela respondeu: "Eu estou tocando o coração da senhora para a senhora tocar o coração das pessoas. Quando estou ruim, falo: toca o meu coração, santa Rita. Em vossos pés deposito todas as minhas angústias e tristezas. Toco o coração para ela sentir o pedido do meu coração, para ela sentir no coração" (devota 1).

A descrição me parece especialmente adequada para recuperarmos as apropriações literais e as elaborações metafóricas que podem ser feitas na relação com as imagens dos santos. Se aparentemente parece haver uma ambiguidade no fato de a santa ser ao mesmo tempo imagem e pessoa, ou no de o coração aparecer ora no sentido literal, como órgão, ora no metafórico, como sendo relacionado às emoções, isso não se coloca como problema para a devota. Pelo contrário, é valendo-se dos dois sentidos que ela tenta sensibilizar e mobilizar a santa, colocando-a em relação com ela mesma e com outras pessoas. A devota toca Santa Rita para que esta toque seus filhos, num sentido que também pode ser literal e metafórico. Para isso, ela emprega não só uma 
linguagem corporal pautada no ato de encostar no coração da santa, mas ainda se vale da linguagem verbal para que suas intenções fiquem bem claras para sua destinatária, usando várias funções da linguagem (Jakobson 1971): a referencial, a metalinguagem (conversa e discorre sobre o que está fazendo com a santa) e a emotiva.

Utilizando-se dessas diferentes funções da linguagem, a devota tenta "tocar o coração" de Santa Rita no sentido literal e também no mais metafórico possível, o de sensibilizá-la para seu pedido ou intenção. O fato de a devota tratar Santa Rita dessa maneira, falando e mostrando à santa o que quer, indica ainda que para algumas pessoas não basta que a Santa saiba o que o devoto necessita; é preciso mostrar-lhe, lembrar-lhe, no sentido de afetá-la: "Eu toco nas mãos dela e digo a ela: ó Santa Rita, a senhora sabe o que eu estou precisando, né?" (devota 18); "Eu toco nela para ela sentir o meu toque" (devota 19).

Todos os casos que venho apresentando mostram que é preciso levar a sério outras ideologias semióticas (Lambek 2012), que pensem as categorias "nativas" a partir de um enquadramento que privilegie não a enunciação referencial, a qual remete para conceitos mais abstratos, e sim outras funções da linguagem, outras maneiras de se analisar os atos de fala. Isso tem me permitido, na pesquisa, complexificar teoricamente, com base nas articulações entre a teoria antropológica, a linguística e a antropologia da devoção, aspectos que já foram considerados por outros autores, como o ato de "tocar" nas imagens dos santos, o qual, como temos visto, envolve várias sutilezas.

Dando prosseguimento a esse exercício, trago o caso de uma senhora que segurava duas folhas de papel na direção dos olhos da imagem de Santa Rita. Quando perguntei a ela o que estava fazendo, ouvi: "é para que ela veja o meu pedido". Essa passagem, bem como os relatos que mostrei mais acima, revela que na visão de alguns fiéis a santa precisa ser literalmente tocada. Esse dado relativiza o senso comum devoto e as interpretações acadêmicas que afirmam que o santo conheceria a necessidade do devoto, sem que este precisasse explicitar algum pedido. Ao mesmo tempo, o fato de muitos fiéis mostrarem à santa o que ela deve saber, entender, ler, sentir, me faz retomar o que Menezes (2004b) falou a respeito da existência de uma pedagogia da devoção. Segundo a autora, esse termo refere-se à atitude de condescendência por parte de pessoas que sabem sobre a devoção ao santo e ensinam aos que não sabem. Fico pensando, a partir dos casos citados acima, se poderíamos complexificar esse conceito de "pedagogia da devoção", mostrando que ela é voltada também para os próprios santos, que devem ser socializados na vida humana, por meio de uma dimensão dialógica com os devotos, construída através do ato de mostrar e dizer para que a santa possa compreender o sentido dos toques, das palavras etc.

Mas as imagens de Santa Rita não apenas recebem estímulos vindos dos devotos. Uma senhora contou que há anos havia prometido à Santa Rita que, se esta a ajudasse a se livrar do marido violento e de seu casamento cheio de agressões, ela, a devota, colocaria sua aliança de ouro no dedo da santa. Ela disse que "este pedido foi 
feito com choro" diante da santa que fica na sacristia e, por isso, até hoje volta sempre na mesma imagem. Após muitos anos tentando obter o divórcio, ela finalmente conseguiu e entregou de presente sua aliança à santa, pedindo ao padre para abrir o vidro do altar, para que deixasse pessoalmente o objeto no dedo da imagem. Perguntei se a devota achava que Santa Rita havia gostado de seu gesto, e ela respondeu dizendo "tenho certeza de que ela gostou porque me deu outra aliança", referindo-se a outro casamento e falando ao mesmo tempo em que apontava para o atual marido, que a acompanhava. Essa narrativa é interessante em dois sentidos. Primeiro, por salientar a devoção como uma relação de trocas que se realimentam. Segundo, porque mostra que, embora a literatura trate a devoção principalmente a partir do devoto, a relação com o santo é fortemente baseada numa cadeia de manifestações de contentamento e descontentamento, aprovação ou desaprovação que a santa (ou o santo) endereça ao devoto, ativando ou mantendo relações. No caso da santa em questão neste artigo, vemos que os fiéis percebem suas manifestações de variadas maneiras: "Essa daqui, eu sinto na expressão dela, quando eu olho para ela vejo o sorriso e digo: Santa Rita, não diga que eu não consigo. Mas hoje ela está com o sorriso lindo, e tenho certeza que ela está muito feliz" (devota 8).

Esses relatos suscitam uma questão importante, pois se a devoção pode abarcar um sistema de comunicação cuja linguagem parece envolver um comportamento técnico-comunicativo de um emissor - o devoto - e ao mesmo tempo um tipo de comportamento "mágico" (Leach 1966), em que ele invoca poderes de seu receptor divino - Santa Rita -, é preciso ponderar que os devotos nos fazem ver que a santa também se constitui como uma poderosa emissora de sinais, e que muitas vezes a interação parte dela, e não deles próprios. Meus interlocutores mostram que não são apenas eles que sentem a presença da santa, mas que também esta os percebe, manifestando-se para seus devotos. A relação ocorre, então, por meio do ato de se olhar reciprocamente, o que pode ocorrer prescindindo de oração ou verbalização: "eu não rezo, eu não preciso rezar, eu olho para ela, ela me entende e eu entendo ela" (devota 16) ${ }^{27}$.

As narrativas dos devotos evidenciam que a santa pode olhar, ler o pedido escrito, expressar emoções, emitir sinais, ser tocada: há dias em que "Santa Rita está triste", e há dias nos quais "ela está feliz". Desse modo, elas reforçam a tese de que os fiéis interagem com uma imagem que, para eles, não é imagem: "Eu amo essa pessoa" (devota 16); "Ela é mulher, e toda mulher gosta de receber flores" (devoto 7).

Já vimos anteriormente que os devotos se referem às partes onde tocam ou passam suas mãos pelos nomes que são usados para designar as partes dos corpos humanos. Eles falam das mãos, dos pés, da cabeça, do rosto, do coração, não como representações da Santa, mas como partes que podem sentir e ser sentidas, ser apalpadas, enfim. Por meio desse repertório de justificativas sobre onde preferem tocar, beijar etc., eles colocam em ação operações rituais que compõem o que seria o corpo de Santa Rita. 


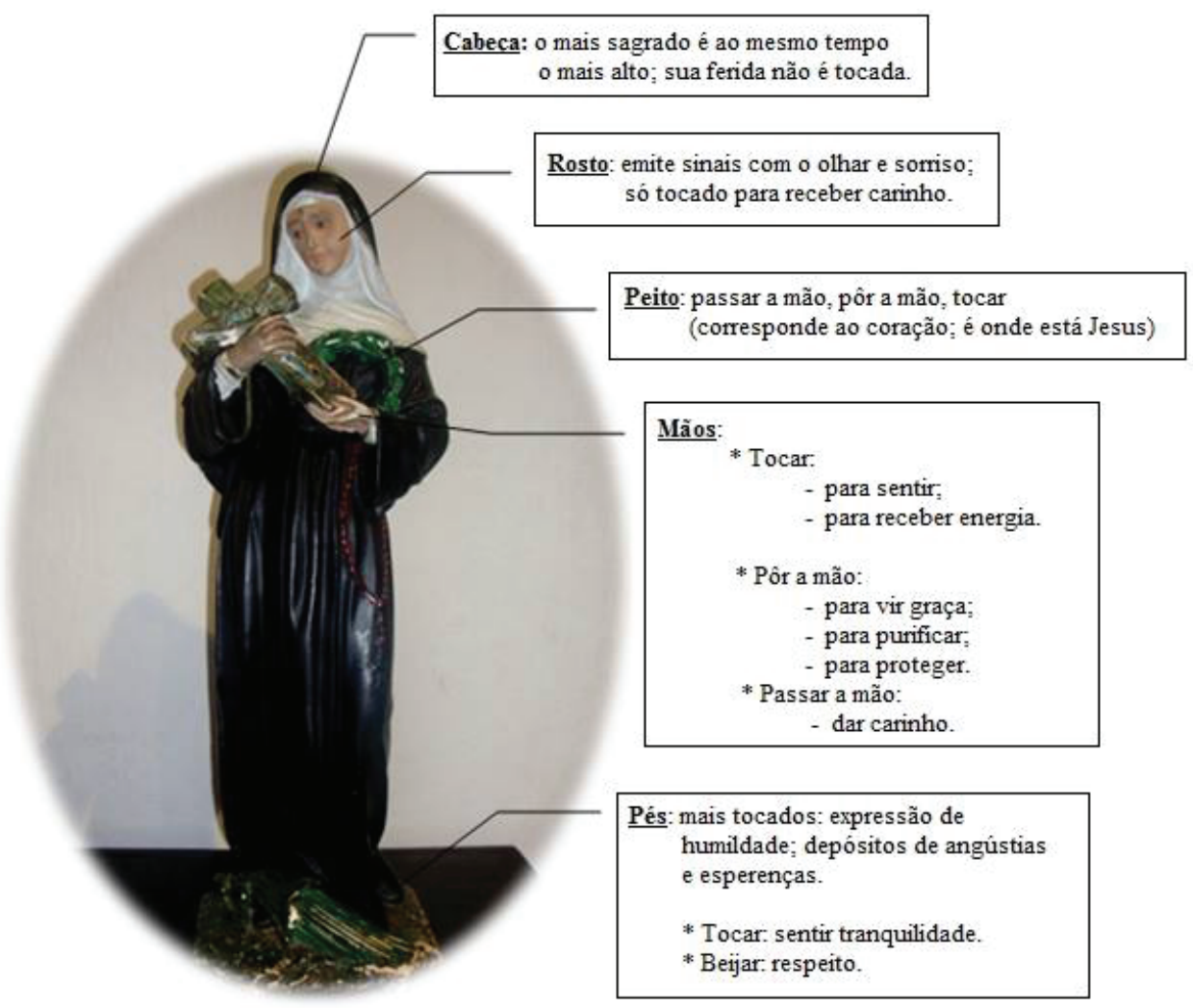

Figura 6: Corpo de Santa Rita (re)composto a partir das interações com os devotos.

Fonte: Raquel Lima.

Embora Santa Rita seja considerada pessoa e seu corpo corresponda, na designação nativa, ao corpo humano, é no seu tratamento que percebemos a especificidade do corpo da santa, quer dizer, onde ele é considerado mais sagrado, não devendo ou podendo ser tocado, bem como atentamos para as variações desse sagrado, já que o pé pode ser menos sagrado para uns, e para outros não. A construção desse corpo é feita pelo uso de palavras referentes ao corpo humano, mas ocorre a partir de um processo de continuidade e diferenciação em relação àquele. É na forma de tratar tais partes da santa, ou seja, é pela manipulação simbólica ${ }^{28}$ de sua imagem que se pode apreender o caráter sagrado desse que também é denominado corpo humano: "Sou muito pequena para passar a mão na cabeça de Santa Rita" (devota 15).

A cabeça, a parte superior do corpo, é também a menos tocada, o que indica que é considerada simbolicamente como sendo mais sagrada. Talvez o máximo que se pode, 
perto da cabeça, seja passar a mão: "gosto de passar a mão no rosto dela", expressando algo mais afetuoso, ou "tocar o rosto para sentir expressão de paz". Apesar de a cabeça e o rosto serem as partes mais interditadas e, nesse sentido, sagradas, é muitas vezes por meio dessas partes que a santa se expressa, valendo-se de qualidades humanas: ela vê, sorri, responde. Ela é sagrada na maneira e nos lugares em que pode ser tocada, mas é humana e ao mesmo tempo sagrada na capacidade de emitir sinais e outras propriedades.

A esta parte mais sagrada, mais alta, corresponde seu oposto, os pés, que são pensados a partir das noções de humildade e de respeito, conceitos estes que podem se combinar, fazendo com que os pés constituam uma das partes mais encostadas e beijadas pelos devotos. Entre estes dois opostos, a cabeça e os pés, estão as mãos, que se destacam sobretudo pela capacidade que têm de transmitir algo, seja o devoto entregando algo de si para Santa Rita (um carinho, um pedido ou uma rosa), seja recebendo algo dela (graça, proteção, purificação, energia). Por fim, o peito e, como parte dele, o coração, que juntos compõem o corpo da santa, que é um corpo ainda diferente, do qual participa o de Jesus Cristo Crucificado, conforme mencionado anteriormente.

Como se vê, Santa Rita é tida como uma pessoa, seu corpo é dotado de partes e de qualidades próprias de um corpo humano, mas esse corpo é complexo, ambíguo e ambivalente, pois apresenta uma parte considerada (mais) sagrada e outra (mais) humana, o que, no entanto, não se configura como um problema para os devotos.

Embora a imagem como representação iconográfica possa ser pensada pelos devotos como se fosse o corpo da santa, existem outros elementos que configuram esse mesmo corpo, mas que só se tornam visíveis quando pensados em termos das partes percebidas e tocadas pelos devotos, isto é, a partir da relação do devoto com a imagem ou vice-versa. Nas análises iconográficas de Santa Rita, não se comenta sobre seus pés ou suas mãos como sendo atributos dela, mas estes são importantes na forma como os devotos concebem o corpo da santa (como vemos em "a mão transmite energia"). Ou seja, além dos atributos clássicos que marcam a imagem da santa, há um corpo que é percebido pelo devoto, e este corpo vai além das representações iconográficas, tornando-se observável por meio das diferentes modalidades de interação com o fiel. Nesse sentido, o corpo de Santa Rita não se encerra em suas imagens ou representações e pode tomar dimensões múltiplas.

As produções simbólicas e as operações rituais em torno da santa e de seu corpo são inúmeras, constantes, diversificadas e até mesmo inusitadas, e mostram que não se pode tomar a noção de presença como algo simples. Além disso, não é só o corpo da santa que está em jogo na relação de devoção, já que a interação com ela ocorre porque também o devoto engaja seu corpo, o que é feito por intermédio de atos corporais, gestos e palavras. Sob esse aspecto, é interessante que muitos fiéis tenham usado o verbo "ir" quando se referiam às partes nas quais encostavam, nas imagens: "Eu vou no peito dela" (devota 17); "Eu vou muito nos pés" (devoto 3). "Ir" na santa é levar seu próprio corpo para se relacionar com o de Santa Rita, pois apesar de os gestos serem direcionados a uma parte do corpo, eles engajam a pessoa inteira (Schmitt 1990). 
Os relatos apresentados ao longo deste artigo nos permitem ver que a presença é, na maioria das vezes, criada ou percebida na interação; além disso, o tratamento dado às imagens de Santa Rita e as diferentes formas de interação entre elas suscitam questões que vão além de uma linguagem corporal da e na devoção, ou das formas devocionais de comunicação. Mais que isso, eles remetem para uma questão antropológica fundamental, que é a discussão da noção de pessoa.

A noção de pessoa tem sido alargada ${ }^{29}$, e um conceito em voga, o de distributed person, pode lançar luz nos estudos sobre os santos, visto que estes, por meio de suas relíquias, imagens, entre outros objetos, teriam a capacidade de se distribuir. Tal como no sentido elaborado por Gell (1998), o da pessoa que se distribui pelos traços ou por suas partes, ou que se distribui entre outras pessoas, os santos difundem-se, multiplicam-se. Este conceito antropológico pautado na ideia da distribuição de uma pessoa me ajuda a pensar a pessoa da santa, que, vimos, é concebida pelos devotos "como se fosse Santa Rita". No entanto, os fatos etnográficos que apresento evidenciam que não há uma única possibilidade de se determinar quem ela é. A santa pode ser uma, como disse o padre ("são todas Santa Rita") e muitas, não sendo a mesma, numa relação uno-múltiplo que permite a cada um ter a sua Santa Rita "preferida", e numa relação de intimidade que varia e permite diversas coisas. Creio que as preferências nativas por algumas imagens nos permitam cogitar que ela não é "uma" pessoa que se distribui nas várias imagens, porque chegam a ser diferentes na forma como se manifestam, nos afetos com os devotos. Elas são muitas! A santa é uma (ou muitas) mulher(es) e, como tal, apresenta gostos socialmente esperados do gênero feminino, como o de gostar de receber flores, por exemplo. Ela tem características de uma pessoa, posto que dotada de sentidos humanos: ela ouve, vê, sente, expressa-se, ao mesmo tempo em que é ambivalente, já que também é considerada sagrada.

\section{Referências Bibliográficas}

BELTING, Hans. (1994), Likeness and Presence: a history of the image before the Era of Art. Chicago: The University of Chicago Press.

BOESCH-GAJANO, Sofia. (1999), "Sainteté”. In: J. Le Goff et J-C. Schmitt (dir.). Dictionnaire raisonné de l'occident médiéval. Paris: Fayard.

BROWN, Peter. (1982), The cult of the saints. Chicago: University of Chicago Press.

BYNUM, Caroline Walker. (1985), "Fast, Feast and Flesh: The Religious Significance of Food to Medieval Women”. Representations, nำ11: 1-25.

DUARTE, Luiz Fernando Dias e GOMES, Edlaine de Campos. (2008), Três famílias: identidades e trajetórias transgeracionais nas classes populares. Rio de Janeiro: Editora FGV.

DUPRONT, Alphonse. (1987), Du sacré. Croisades et pèlerinages. Images et langages. Paris: Éditions Gallimard.

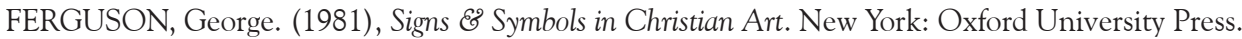

FREEDBERG, David. (1992), El poder de las imágenes. Estúdios sobre la historia y la teoria de a respuesta. Madrid: Cátedra. 
GELL, Alfred. (1998), "Distributed person". In: A. Gell. Art and Agency: an anthropological theory. Oxford: Oxford University Press.

GINZBURG, Carlo. (2001), Olhos de madeira: nove reflexões sobre a distância. São Paulo: Companhia das Letras.

GOLDMAN, Márcio. (1994), Razão e diferença. Afetividade, racionalidade e relativismo no pensamento de Lévy-Bruhl. Rio de Janeiro: Editora Grypho/Editora da UFRJ.

GOMES, Lilian Alves. (2013), "O êxtase dos objetos: ex-votos e relações de devoção". Interseções, v. 15: $172-193$.

JAKOBSON, Roman. (1971), Linguística e comunicação. Tradução de I. Blinkstein e José P. Paes. São Paulo: Cultrix.

KING, E. Frances. (2010), Material religion and popular culture. New York: Taylor \& Francis.

KONDO, Dorinne. (1984), "The way of tea: a symbolic analysis”. Man, v. 20: 287-306.

LAMBEK, Michael. (2012), "Facing religion, from Anthropology". Anthropology of this century, issue 4.

LATOUR, Bruno. (2004), "Não congelarás a imagem, ou: como não desentender o debate ciência-religião". Mana, v. 10, no 2: 349-375.

. (2008), "O que é iconoclash? Ou, há um mundo além das guerras de imagem?". Horizontes antropológicos [online], v. 14, no 29, p. 111-150. Disponível em: http://dx.doi.org/10.1590/ S0104-71832008000100006. Acesso em: 20/07/11.

LEACH, Edmund. (1966), "Ritualization in man”. In: S. Hugh-Jones \& J. Laidlaw (eds.). The Essential Edmund Leach. New York: Yale University Press.

LIMA, Raquel dos Santos Sousa. (2014), "É como se fosse Santa Rita": processos de simbolização e transformações rituais na devoção à Santa dos impossíveis. Rio de Janeiro: Tese de Doutorado em Antropologia Social, PPGAS/MN/UFRJ.

LOSONCZY, Anne-Marie. (1997), Les saints et la forêt. Rituel, société et figures de l'échange avec les Indiens Emberá chez les Négro-Colombiens du Chocó. Paris: L'Harmattan.

MAUSS, Marcel. (1981), “A prece”. In: M. Mauss. Ensaios de Sociologia. São Paulo: Perspectiva. . (1974), "As técnicas corporais". In: M. Mauss. Sociologia e Antropologia. São Paulo: EPU/Edusp.

. (2004), "Ensaio sobre a dádiva. Forma e razão da troca nas sociedades arcaicas". In: M. Mauss. Sociologia e Antropologia. São Paulo: Cosac Naify.

MAUSS, Marcel; DURKHEIM, Émile. (2001), "Algumas formas primitivas de classificação. Contribuição para o estudo das representações coletivas". In: M. Mauss. Ensaios de Sociologia. São Paulo: Perspectiva.

MENEZES, Renata de Castro. (2004a), "Saber pedir: a etiqueta do pedido aos santos". Religião e Sociedade, v. 24, nº 1: 46-64.

(2004b), A dinâmica do sagrado: rituais, sociabilidade e santidade num convento do Rio de Janeiro. Rio de Janeiro: Relume Dumará - Núcleo de Antropologia da Política/UFRJ.

. (2010), Os Santos e a reciprocidade: ou o que a Antropologia pode fazer pelos estudos da devoção [e vice-versa]. Rio de Janeiro: Palestra em 14 de maio de 2010. Nucec/PPGAS/MN/UFRJ. Manuscrito.

MILES, Margaret R. (1998), “Image”. In: M. C. Taylor (ed.). Critical Terms for Religious Studies. Chicago, London: University of Chicago.

O'NEIL, J. (1968), "Saints, devotion to the". In: The New Catholic Encyclopedia. Nova York: McGrawn \& Hill Ed., v. 12.

PITT-RIVERS, Julian. (1992), "Post-script: the place of grace in anthropology". In: J. G. Peristiany; J. Pitt-Rivers. Honor and Grace in Anthropology. New York: Cambrige University Press.

RABELO, Miriam C. (2011), "Estudar a religião a partir do corpo: algumas questões teórico-metodológicas". Cad. CRH [online], v. 24, nº 61: 15-28. Disponível em: http://www.scielo.br/pdf/ccrh/ v24n61/02.pdf. Acesso em: 15/12/13. 
SÁIZ, Antonio Iturbe. (2000), "La iconografia de Santa Rita em España e Hispanoamérica". In: Studia Augustiniana Historica. Santa Rita da Cascia Storia Devozione Sociologica. Atti Del Congresso Internazionale in occasione del Io centenário della canonizzazione celebrato a Roma, 1998. Roma: Institutum Historicum Augustinianum.

SCARAFFIA, Lucetta. (1990), La santa degli impossibili. Vicende e significati della devozione a Santa Rita. Torino: Rosenberg \& Sellier.

SCHMITT, Jean-Claude. (1990), La raison des gestes. Paris: Gallimard.

(2007), O corpo das imagens. Ensaio sobre a cultura visual na Idade Média. Tradução de José Rivair Macedo. Bauru, SP: EDUSC.

TAMBIAH, Stanley. (1985), Culture, Thought, and Social Action: An Anthropological Perspective. Cambridge, MA: Harvard University Press.

TURNER, Victor. (1978), "Iconophily and Iconoclasm in Marian Pilgrimage". In: V. Turner; E. Turner. Image and Pilgrimage in Christian Culture: anthropological perspectives. Oxford: Basil Blackwell. nell Univ. Press. . (1967), "Symbols in Ndembu ritual". In: V. Turner. The Forest of Symbols. Ithaca: Cor-

VERNANT, Jean-Pierre. (1973), “A categoria psicológica do ‘duplo’”. In: J-P. Vernant. Mito e Pensamento entre os Gregos. São Paulo: Difel, Edusp.

. (1992), "Figuração e Imagem". Revista de Antropologia, no 35: 113-128.

\section{Notas}

1 Trata-se da tese intitulada "É como se fosse Santa Rita": processos de simbolização e transformações rituais na devoção à santa dos impossíveis, defendida em fevereiro de 2014, no Programa de Pós-Graduação em Antropologia Social do Museu Nacional da Universidade Federal do Rio de Janeiro. A pesquisa contou com recursos da Bolsa de Doutorado do CNPq e da Bolsa Sanduíche da FAPERJ.

2 Neste artigo, as aspas serão utilizadas principalmente para distinguir as falas de meus interlocutores: fiéis, padres e outras pessoas com quem dialoguei em campo. Além disso, podem aparecer como marcadores de trechos de determinados autores, o que, quando acontecer, será devidamente especificado.

3 A novena é um tipo especial de oração, realizada durante nove dias seguidos, que geralmente antecedem o dia principal das festas dos santos. Como a Festa de Santa Rita ocorre em 22 de maio, sua novena é realizada entre os dias 13 e 21.

4 Este gesto traduz-se pela execução do desenho da cruz entre a cabeça e o peito, ao mesmo tempo em que se recita uma invocação. Com a mão direita, toca-se levemente a testa ("em nome do Pai"), em seguida o peito (“do Filho"), o ombro esquerdo (“do Espírito Santo”), depois o direito (“amém”). De acordo com Mauss (1981), o gesto seria a fórmula inicial da maior parte das orações sacramentais no catolicismo, com valor evocativo, colocando a coisa que solenizam sob a proteção de um ser que nomeiam e tornam presente.

5 De acordo com a teologia católica, os santos devem ser reverenciados: "supernatural dulia, the honor paid to the saints, pertains to the virtue or reverence (observantia). It honors that excellence of virtue and intercession which is given the saints by grace. Concretely, invocation of the saints, since it seeks their intercession for blessings which only God can give, involves the activity of both religion and reverence under direction of the theological virtues" (O’Neil 1968:963).

6 A primeira figura mostra as diferentes imagens do culto à Santa Rita naquela igreja, as quais são identificadas com a sigla SR, para facilitar o acompanhamento da descrição pelo leitor. Já a segunda figura apresenta um esboço com a localização das mesmas no templo. Agradeço à arquiteta Patrícia Lacerda e à Fabiana Filipino a colaboração na produção deste e de outros esboços.

7 A partir de um estudo feito por Sáiz (2000) sobre a iconografia da santa na Espanha e na Hispanoamérica, é possível dizer que os estilos contidos em SR1 e SR2 podem ser associados a dois pe- 
ríodos distintos: um, que vai desde a Beatificação da Santa (1628) até a independência dos países hispano-americanos (primeira metade do século XIX), e outro, que vai da canonização da santa (1900) até os dias atuais.

8 No final da Festa de 2011, tive a oportunidade de ficar bem perto desta imagem, quando fui chamada pelo pároco para ajudar na limpeza do altar-mor. Foi então que pude perceber que, apesar de todos falarem que aquela seria uma "cópia idêntica" da primitiva imagem de 1750, que fica na sacristia, há pequenas diferenças entre elas, sobretudo na pintura facial, na palma e no esplendor, detalhes que não podem ser vistos por quem olha para a santa de longe.

9 Em sua análise dos signos e símbolos da arte cristã, Ferguson (1981) afirma que a palma usada pelos santos muitas vezes está relacionada a seus martírios e sugere o triunfo desses mártires sobre a morte.

${ }^{10}$ Apesar de haver várias imagens de diferentes santos na igreja, que poderiam ser analisadas a partir de suas combinações, como fez Menezes (2004b) em seu estudo sobre Santo Antônio, aqui estou interessada em analisar as relações entre as imagens da mesma santa.

${ }^{11}$ Esta discussão é debatida em diferentes campos disciplinares e pode ser conferida nos seguintes autores: Turner (1978); Brown (1982); Menezes (2004b); Miles (1998); Latour (2004, 2008); Schmitt (2007); Ginzburg (2001); Freedberg (1992); Vernant (1973, 1992); Belting (1994); Dupront (1987).

${ }^{12}$ Esta noção de ambivalência é inspirada na análise que Alphonse Dupront faz sobre as imagens. Ele argumenta que elas são, "dans sa matérialité, support d'ambivalence. Silencieuse, atemporelle, banalisée ou, ce qui est pire, abusivement élaborée jusqu'à devenir muette, elle presente tous traits et stigmates d'une passivité décorative, voire d'une surabondance étalée, à moins que par son insolente et empoignante beauté elle n'ensorcelle en sa propre suffisance. Mais en sa passivité d'objet, la voici cependant oferte à la piété commune et nourriture souvent essentielle de celle-ci, active à fixer le regard, à susciter l'éveil de l'imaginaire. Physiquement passive, elle doit être, du fait simplement qu'elle existe, source d'âme. Ambivalence, donc richesse existentielle singulière, mais qui - c'est sans doute la juste grandeur de l'image de religion - la dépouille d'autant plus de toute existence propre, pour lui rendre sa vertu d'être simple moyen ou supportt" (1987:13).

${ }^{13}$ No quinto capítulo de minha tese (Lima 2014), mostro como esse vidro, a partir de sua utilização em um ritual ligado à troca de rosas diante da imagem da sacristia, pode ser pensado como extensão da pessoa de Santa Rita.

${ }^{14}$ Os ex-votos compreendem uma categoria diversificada de objetos religiosos que são deixados para os santos como pagamento de promessas, agradecimentos por graças alcançadas etc. (Gomes 2013).

${ }_{15}$ As rosas, embora sejam comumente utilizadas no culto aos santos, configuram-se, na devoção à Santa Rita, como um símbolo da santa, que teria realizado o milagre de fazer surgir rosas durante um inverno rigoroso. Nesta igreja carioca há diversas atividades de culto associadas às rosas, e as principais são a "Benção das Rosas" e a "Entrega das Rosas", que engendram diversas modalidades de trocas rituais de rosas entre os devotos e Santa Rita.

${ }^{16}$ Faço uso aqui da noção de "relação de devoção", tal qual elaborada pela antropóloga Renata Menezes, que afirma que "a relação de devoção passa por considerar determinados aspectos da vida do santo e do devoto como 'relacionados', no sentido de haver entre eles elementos de identidade que servem de base para estabelecer vínculos significativos" (Menezes 2004b:238).

${ }^{17}$ Entre eles destaco Miles (1998); Turner (1978); Boesch-Gajano (1999); Schmitt (2007); e King (2010).

${ }^{18}$ Menezes $(2004 b, 2010)$ tem enfatizado a importância do conceito da "graça" nas análises sobre o culto aos santos, mostrando que, apesar de os pedidos dirigidos a estes serem um elemento criador e mantenedor da relação de devoção, a graça igualmente se constitui, para os fiéis, como um importante fator dessa relação, já que o devoto "parece viver em um permanente estado de graça" (2004b:230). Sobre a questão da graça, pode-se ainda conferir Pitt-Rivers (1992).

${ }^{19}$ O medievalista Jean-Claude Schmitt (1990) afirma que a humildade seria uma categoria fundamental e uma constante no catolicismo, com raízes nas Sagradas Escrituras, evidenciada em passagens bastante difundidas entre os adeptos dessa religião, como a do relato no qual Jesus Cristo, em sua última 
ceia com os apóstolos, teria lavado os pés destes, deixando, assim, um exemplo de humildade e serviço ao próximo.

${ }^{20}$ Embora algumas vezes o beijo seja percebido com uma conotação negativa por alguns devotos, é preciso lembrar que o ato de beijar aparece em vários relatos bíblicos, tendo sido um elemento do contato fraternal (chamado de ósculo santo) entre Cristo e seus discípulos, o que salienta seu caráter sagrado.

${ }^{21}$ Inspiro-me, novamente, na noção de etiqueta, formulada por Renata Menezes. A partir de seu estudo sobre o culto a Santo Antônio, ela argumenta que o detalhamento dos pedidos permitiu entender que a questão da sabedoria necessária para fazer um pedido aparecia de duas maneiras no convento. Primeiro, no sentido da realização de um pedido eficaz: uma pessoa acostumada a pedir a um santo é capaz de manejar estratégias para fazer o pedido de forma a conseguir que ele se realize. Trata-se, no caso, de deter o conhecimento das idiossincrasias e capacidades de cada santo, de saber comovê-lo, de levá-lo a conceder aquilo que foi pedido. Segundo, no sentido de o pedido feito ao santo ter certa adequação (Menezes 2004a:59).

${ }^{22}$ Segundo o autor, iconoclash "é quando não se sabe, quando se hesita, quando se é perturbado por uma ação para a qual não há maneira de saber, sem uma investigação maior, se é destrutiva ou construtiva" (Latour 2008:113).

${ }^{23}$ De acordo com o antropólogo, "a lei da participação não passaria de um esforço de aproximação, de uma tentativa de dar forma um pouco mais compreensível para o fato da participação, característico das representações coletivas primitivas. Ele implica, no primeiro sentido, uma rede de ligações, interpenetrações e dependências de todos os seres e coisas do universo entre si. Tudo e todos estariam mergulhados numa espécie de consubstancialidade universal, que faria com que cada elemento estivesse, de modo misterioso, conectado a todos os demais" (Goldman 1994:199).

${ }^{24}$ Lembremos que Santa Rita se constitui como exemplo de "união mística" com Deus, o que era uma característica histórica da religiosidade feminina medieval que, por meio de uma linguagem corporal baseada em flagelos corporais, jejuns penitenciais, e de uma devoção acentuada ao corpo e ao sangue de Cristo, uniria seu corpo sofrido ao do Cristo sofredor (Bynum 1985; Schmitt 1990).

${ }^{25}$ Afirmo que o coração da santa é suposto pelos devotos, já que ele não é um atributo da santa, como ocorre, por exemplo, com o Sagrado Coração de Jesus ou o Sagrado Coração de Maria, em cujas imagens este órgão é representado externamente.

${ }^{26}$ No artigo em que discute alguns caminhos analíticos que a reflexão sobre o corpo nas ciências sociais contemporâneas abre para o estudo da religião, a antropóloga Miriam Rabelo, partindo de sua pesquisa no candomblé e no pentecostalismo, afirma que o corpo "estende-se para fora, abre-se aos lugares e sintoniza-se às coisas e pessoas que constantemente o solicitam. Incorpora objetos e, não raro, é incorporado a séries de objetos. Seu alcance e suas fronteiras são móveis - não preexistem à ação ou ao movimento, mas definem-se nele" (Rabelo 2011:26).

${ }^{27}$ Nesse sentido, o olhar sereno ou beatífico que a devota percebe na santa lembra a importância do ato de olhar na experiência religiosa (Dupront 1987).

${ }^{28}$ Como sugere Anne-Maire Losonczy, "la corporalité des saints, ancrée dans leurs représentations iconographiques est attestée par le traitement rituel de celles-ci et par les commentaires" (Losonczy 1997:192).

${ }^{29}$ Sobre esta questão, Luiz Fernando Duarte e Edlaine Gomes oferecem um bom resumo, mostrando que "a noção de que a 'pessoa', como nódulo de agência definido por uma determinada cultura, não tem necessariamente como substrato um 'indivíduo biopsicológico' tem crescido na antropologia contemporânea, sobretudo graças à comparação etnológica” (Duarte e Gomes 2008:274).

Recebido em novembro de 2014. Aprovado em março de 2015. 
Raquel dos Santos Sousa Lima (raquelssousalima@gmail.com) Professora do Colégio de Aplicação da Universidade Federal de Viçosa. Doutora em Antropologia Social pelo Programa de Pós-Graduação em Antropologia Social do Museu Nacional da Universidade Federal do Rio de Janeiro. 


\section{Resumo:}

Sobre presença e representação nas imagens dos santos católicos: considerações a partir de um estudo sobre a devoção à Santa Rita

As imagens tridimensionais dos santos católicos têm sido analisadas por uma ampla literatura - antropológica e histórica - a partir principalmente da discussão sobre as noções de presença e de representação. Baseada numa observação minuciosa sobre as formas de interação entre os devotos e as imagens de Santa Rita numa igreja sob sua invocação na cidade do Rio de Janeiro, recupero concepções "nativas" que permitem complexificar o uso das categorias de presença e de representação nas análises sobre as devoções aos santos. Ao mesmo tempo, mostro como essas categorias implicam o uso de outras concepções antropológicas importantes, como as de corpo e de pessoa, discussão que faço a partir das contribuições da antropologia dos objetos, da devoção, dos rituais e do simbolismo.

Palavras-chave: imagens, presença, representação, culto aos santos.

\section{Abstract:}

Presence and representation in images of Catholic saints: considerations from a case study on the devotion to Saint Rita

Three-dimensional images of Catholic saints have been analyzed by a wide anthropological and historical literature mainly from notions of presence and representation. This work examines the interaction between devotees and the images of Saint Rita in a church dedicated to her in Rio de Janeiro. The paper focuses on "native" conceptions to make the uses of presence and representation more complex when analyzing devotions to the saints. By considering discussions about the anthropology of objects, devotion, rituals and symbolism, it shows how the relationship with images of saints implies the use of other key anthropological concepts such as body and person.

Keywords: images, presence, representation, cult of the saints. 